\title{
Utilidad de la termografía para evaluar cambios fisiológicos en árboles de pomelo regados con agua regenerada y riego defici- tario combinado.
}

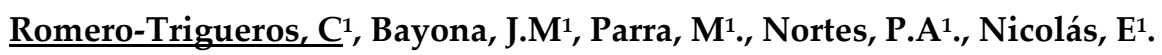

Irrigation Department, Centro de Edafología y Biología Aplicada del Segura, CSIC, P.O. Box 164, 30100, Espinardo (Murcia), Spain. cromero@cebas.csic.es

Resumen: Los cítricos son uno de los cultivos frutales comerciales más importantes a nivel mundial, incluido el sureste de España, donde el clima es semiárido y la escasez de recursos hídricos para la agricultura precisa del uso de estrategias de ahorro de agua, como el riego deficitario regulado (RDC), o fuentes de agua no convencionales, como el agua regenerada (AR). No obstante, la aplicación de estas estrategias requiere un adecuado manejo del riego y una previa caracterización del estado hídrico de la planta mediante herramientas eficaces. En este trabajo se evaluó la utilidad de la termografía para monitorear los cambios diurnos en la fisiología de árboles de pomelo regados con AR salina y/o RDC. Se midieron varios parámetros fisiológicos a nivel de hoja (potencial hídrico del tallo - $\Psi_{\text {tallo }}$-, conductancia estomática $-\mathrm{g}_{\mathrm{s}^{-}} \mathrm{y}$ clorofila total -Chl T-) e índices térmicos (temperatura del dosel -Tc-, diferencia entre la temperatura del dosel y del aire -Tc-Ta-, índice del estrés hídrico del cultivo -CWSI- e índice de conductancia estomática -IG-). En general, los resultados mostraron una significativa correlación entre los datos fisiológicos y térmicos. La Tc y la Tc-Ta se consideraron buenos indicadores para estimar

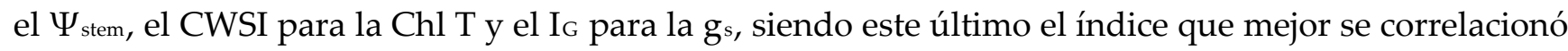
con todos los parámetros fisiológicos (mayor significación en los coeficientes de correlación) y, especialmente, con $\mathrm{g}_{\mathrm{s}}$ al mediodía. Dado que la conductancia estomática se ha definido recientemente como el mejor indicador del estado hídrico del pomelo (isohídrico), aquí nosotros sugerimos que el índice IG, medido mediante termografía, fue el indicador más útil en pomelos regados con AR y RDC.

Palabras clave: Cítricos; clorofila; conductancia estomática; CWSI; potencial hídrico del tallo; temperatura del dosel. 


\title{
XXXVIII Congreso Nacional de Riegos
} CARTAGENA 2021

\section{Thermal imaging to assess physiological changes of grapefruit trees irrigated with reclaimed water combined with deficit irri- gation}

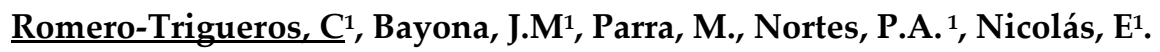

Irrigation Department, Centro de Edafología y Biología Aplicada del Segura, CSIC, P.O. Box 164, 30100, Espinardo (Murcia), Spain. cromero@cebas.csic.es

\begin{abstract}
Citrus is one of the most important commercial fruit crops worldwide, including the southeastern Spain, where climate is semi-arid Mediterranean and water is not always accessible for agriculture. In order to overcome this problematic, the use of water-saving strategies such as regulated deficit irrigation (RDI) or non-conventional water sources such as saline reclaimed water (RW) are alternatives for farmers. Nevertheless, an adequate irrigation management previous characterization of plant water status by means of reliable tools is necessary when applying these strategies. In this work, the usefulness of the thermal imaging (thermography) for monitoring the diurnal changes in the physiology of grapefruit trees irrigated with saline RW and/or RDI was assessed. Discrete physiological indicators (stem water potential $-\Psi_{\text {stem - }}$, stomatal conductance $-\mathrm{g}_{\mathrm{s}^{-}}$and leaf total chlorophyll $-\mathrm{Chl} \mathrm{T}-$ ) and thermal indices (canopy temperature -Tc-, the difference between canopy and air temperature -Tc-Ta-, crop water stress index -CWSI-, and stomatal conductance index -IG-) were measured during a daily evolution. Results, in general, showed excellent relationship between physiological and thermal data. The most suitable thermal indicators were: Tc and Tc-Ta to estimate $\Psi_{\text {stem, }} \mathrm{I}_{\mathrm{G}}$ to $\mathrm{g}_{\mathrm{s}}$, and CWSI to Chl T. Overall, IG was the index that better was related with all the physiological parameters (higher significance in the coefficients of correlation) and, specially, with $\mathrm{gs}_{\mathrm{s}}$ at midday. Since stomatal conductance was recently considered the best indicator of the grapefruit water status (isohydric), we suggest here that the $I_{G}$ index measured by thermography was the more useful thermal indicator of grapefruit trees irrigated with saline RW and RDI.
\end{abstract}

Keywords: Canopy temperature; citrus; chlorophyll; crop water stress index; stem water potential; stomatal conductance. 


\section{Introduction}

Water is essential for agricultural production. However, climate change is influencing the availability of water resources worldwide, reducing renewable surface water and groundwater resources at an alarming rate in most arid and semiarid regions [1] as the south-eastern Spain, where Citrus is one of the most important commercial fruit crops. It is estimated that by 2025, round 2 billion people will be affected by water scarcity [2], with a potential impact on agricultural production. Strategic approaches to the optimization of water management include regulated deficit irrigation (RDI), where water deficits are imposed during the phenological periods when fruit trees are less sensitive to water stress, with little impact on yield [3]. Also, non-conventional water sources, as a component of effective water conservation strategies, are required in agriculture in water-limited regions [4]. In this sense, reused reclaimed water (RW) is considered a non-expensive and reliable alternative source. This water usually contains essential nutrients, beneficial for crop growth and for the growers in economic terms, but also salts and toxic ions which discharge into the wider environment and can accumulate in soil and crops overtime, with negative consequences for soils, plant physiology and yield, and underground water bodies [5]. These impacts of RW have been studied at the plant agro-physiology and ecosystem levels [6-14] for crops such as citrus, almond and olive. Nevertheless, an adequate irrigation management previous characterization of plant water status by means of reliable tools is necessary when applying these two strategies. The selection of this kind of indicators is crucial since a balance must be found between the sensibility of measuring the crop water status and the capability to implement its measurement [15]. Stem water potential $\left(\Psi_{\text {stem }}\right)$ is considered to be the parameter par excellence for the estimation of the crop water status. However, it is a destructive, non-automatable and very time-consuming method, which implies discontinuous measurements. Besides, recently, stomatal conductance has been considered as the best and most accurate physiological indicator of crops with a near isohydric behaviour as is grapefruit irrigated with RW and RDI [14]; though, their measures are also punctual, laborious and time consuming. Other of the most extended variables used in providing insight into crop water status is plant temperature. The leaf temperature is affected by the stomatal aperture, which is influenced by plant and soil water status as well as meteorological conditions, as it acts as a cooling mechanism by controlling the evapotranspiration [14]. The higher the crop water stress, the lower the stomatal aperture in order to prevent the plant from water exhaustion, thus leading to an increase of leaf temperature and, in general, the canopy temperature (Tc), defined as the average T of multiple leaf assemblages aggregated from individual branches up to whole crowns by [16]. Then, the Tc links directly to plant water stress [17]. Other physiological traits, as $\Psi_{\text {stem }}$ or total leaf chlorophyll content (Chl T) also can influence canopy water exchanges. Though these interactions are relatively straightforward to estimate in isolated leaves, they are much more challenging to model and measure at the canopy scale. Critically, many of these properties can vary across non-homogeneous canopies as a function of canopy position, and even within species and individual crowns [18]. Several techniques can be found to measure the Tc. Infrared thermoradiometers (IRT) are widely used and one of the most popular options providing remote measurement and field installation robustness. Nonetheless, the main drawback of IRT is that both emitted and reflected radiation from the different sources covered by the field of view is integrated in the bulk measurement, thus, hampering the determination of Tc exclusively [15]. Alternatively, thermal imaging (thermography) integrate a larger number of leaves for the T measurement and could be, in some cases, more appropriate than methods that rely only in a few leaves from a specific location of the canopy as it happens with the fixed IRT [17]. For this, thermography is being widely applied, including from handheld [19], fixed on site [20] or land vehicle-attached devices 


\section{Congreso Nacional de Riegos CARTAGENA 2021}

[21] to airborne vehicles [22] and satellites [23]. To our knowledge, so far few studies have been published about the usefulness of thermography in citrus under water stress [17], and nothing under saline RW.

Here, in order to evaluate the effects of water and saline stresses on plant physiology and the suitability of different thermal indicators obtained by thermal imaging, hourly changes in the $\Psi_{\text {stem, the }}$ stomatal conductance $\left(\mathrm{g}_{\mathrm{s}}\right)$, the $\mathrm{Chl} \mathrm{T}$, and the Tc, were measured at the end of the RDI period, on DOY 257 at two times: early morning $\left(t_{1}, 08.00\right.$ GMT) and near midday $\left(t_{2}, 11.00\right.$ GMT). Then, different thermal indices (Tc-Ta, the stomatal conductance index -IG- and the crop water stress index -CWSI-) were calculated. Thus, the main aims were: i) assess the effects of irrigation with RW and RDI on plant physiology at two times of the day with different evaporative demand; ii) the suitability of Tc measurement by thermography, iii) the best thermal indicator of the plant water status, and iv) the appropriate moment to take the thermal readings. We hypothesize that the treatment that combines both stresses (RW and RDI) will be the most physiologically affected. The more useful indicator will be the one that best correlates with stomatal conductance, since grapefruit is an isohydric crop.

\section{Materials and methods}

Study area and irrigation treatments. The experiment was conducted at a commercial citrus orchard, located to the Northeast of the Murcia region in Campotéjar, $7 \mathrm{~km}$ north of Molina de Segura $\left(38^{\circ} 07^{\prime} 18^{\prime \prime} \mathrm{N}, 1^{\circ} 13^{\prime} 15^{\prime \prime} \mathrm{W}\right)$. The experimental plot of 0.5 ha was cultivated with adult 'Star Ruby' grapefruit trees (Citrus paradisi Macf) grafted onto Macrophylla rootstock (Citrus macrophylla) planted at 6 $\times 4 \mathrm{~m}$. The irrigation scheduling and experimental design are described in more detail in $[3,9,14]$. All trees received the same amount of fertilizers, which were applied through the drip irrigation system of $215 \mathrm{~kg} \mathrm{~N}, 110 \mathrm{~kg} \mathrm{P}_{2} \mathrm{O}_{5}$ and $150 \mathrm{~kg} \mathrm{~K}_{2} \mathrm{O} \mathrm{ha}^{-1} \cdot$ year $^{-1}$. Weeds were eradicated in the orchard by applying the farmers' commonly used pest control methods. The plot was always irrigated with two water sources. The first irrigation water was pumped from the Tajo-Segura canal (transfer water, TW) and, the second one, from the North of "Molina de Segura" tertiary WWTP (reclaimed water, RW). The latter had high salt and nutrient levels with a high electrical conductivity (EC) close to $4 \mathrm{dS} \cdot \mathrm{m}^{-1}$, while, for the $\mathrm{TW}$, the EC values were close to $1 \mathrm{dS} \cdot \mathrm{m}^{-1}$. Saline water was automatically mixed with water from TW at the irrigation control-head to lower its $\mathrm{EC}$ to $\approx 3 \mathrm{dS} \cdot \mathrm{m}^{-1}$ in order to establish a constant EC during the experiment. Two irrigation treatments were established for each water source: a control (C) in which the crop was irrigated according to water requirements $\left(100 \% \mathrm{ET}_{\mathrm{c}}\right)$, and a regulated deficit irrigation (RDI), applying only $50 \%$ of $E T_{c}$ during the second phase of rapid fruit growth. RDI period began on DOY 185 (4 July) and ended on DOY 260 (17 September). The daily evolution was carry out on DOY 257. The physiological and thermal measurements were carried out twice a day: at 08.00 GMT $\left(\mathrm{t}_{1}\right)$ and at $11.00 \mathrm{GMT}\left(\mathrm{t}_{2}\right)$.

Physiological crop response. Physiological data were measured in order to obtain the plant-truth data. Stomatal conductance $\left(g_{s}\right)$ and stem water potential $\left(\Psi_{\text {stem }}\right)$ were determined on eight fully-expanded leaves from the mid-shoot area of each tree per treatment (two leaves from each replicate). The $g_{s}$ was determined with a portable photosynthesis system (LI-6400 Li-Cor, Lincoln, Nebraska, USA) as described by [7]. The $\Psi_{\text {stem }}$ was determined using a pressure chamber (model 3000, Soil Moisture Equipment Corp., California, USA) as described by [10]. The osmotic water potential at full turgor ( $\left.\Psi_{100 s}\right)$ and leaf chlorophyll determination was carried out as described by [14] and [7], respectively. Osmotic adjustment was calculated by [14].

Thermal response. Average canopy temperatures (Tc) were measured using thermography twice in the course of the day (at $t_{1}$ and $t_{2}$ ) from the sunlit side of the canopy [24] in eight plants per irrigation 


\section{Congreso Nacional de Riegos CARTAGENA 2021}

treatment. One thermal image from the canopy, from each of the eight plants per treatment, was obtained from a constant distance $(\mathrm{d})$ of $0.5 \mathrm{~m}$. The selected plants were the same on which gas exchange was immediately measured. Thermal images were obtained manually with a thermal imager (ThermaCam FLIR-e50 System, Inc., Danderyd, Sweden). Camera features and input used are described by [25]. Where the canopy was imaged, dry and wet reference leaves were used to simulate leaves with fully closed and fully open stomata, respectively [24]. Wet reference leaves were sprayed with water to maintain their moisture level, and dry reference leaves were covered both sides with petroleum jelly. Thermal images were processed with ThermaCam Explorer software (FLIR Quick Report, FLIR Systems, Danderyd, Sweden). Tc for each thermal image was obtained as the average of delimited portions of mature leaves, excluding reference leaves. The temperatures of the reference leaves $\left(\mathrm{T}_{\text {wet }}\right.$ and $\left.\mathrm{T}_{\mathrm{dry}}\right)$ included in the thermal image were obtained as the mean values of each of them (see in [25]). The temperatures of the reference leaves $\left(\mathrm{T}_{\text {wet }}\right.$ and $\mathrm{T}_{\mathrm{dry}}$ ) in conjunction with $\mathrm{Tc}$ were used to obtain thermal indices: the stomatal conductance index $\left(\mathrm{I}_{\mathrm{G}}\right)$ and the crop water stress index (CWSI). The index IG = $\left(\mathrm{T}_{\mathrm{dry}}-\mathrm{Tc}\right) /\left(\mathrm{Tc}-\mathrm{T}_{\mathrm{wet}}\right)$ is theoretically proportional to stomatal conductance of water vapour (Jones et al., 2002). The CWSI $=\left(\mathrm{T}_{\mathrm{dry}}-\mathrm{Tc}\right) /\left(\mathrm{T}_{\mathrm{dry}}-\mathrm{T}_{\text {wet }}\right)[26]$ commonly varies between 0 and 1 . Values close to 0 indicate a fully transpiring leaf/crop (i.e. no stress); whereas values close to 1 indicate a non-transpiring leaf/crop (i.e. maximum stress). The air temperature was obtained from several thermoradiometers placed in the upper part of the tree canopies in the experimental plot.

Statistical analysis and experimental design. A weighted analysis of variance (ANOVA) followed by Tukey's test $(\mathrm{P} \leq 0.05)$ was used for assessing differences among treatments. Linear regressions among the physiological variables and thermal data were calculated. Pearson's correlation coefficients were used to assess the significance of these relationships. These statistical analyses were performed using SPSS (vers. 23.0 for Windows, SPSS Inc., Chicago, IL, USA). The experimental design of each irrigation treatment was 4 replicate distributed following a completely randomized design. Each replicate consisted of 12 trees, organized in 3 adjacent rows. Two trees of the middle rows from each replication were used for measurements and the rest acted as guards and were excluded from the study to eliminate potential border effects.

\section{Results and discussion}

\subsection{Effects of water and saline stress on the water relations and leaf chlorophyll}

Regarding the water relations, both water and saline stress reduced significantly the $\Psi_{\text {stem }}$ and $g_{s}$ respect to the control trees in the two samplings, mainly RW-RDI. This treatment showed the lowest

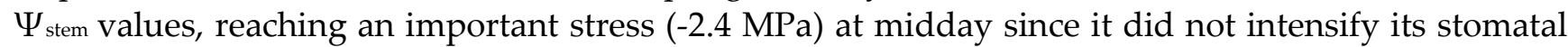
closure; that is, its $\mathrm{g}_{\mathrm{s}}$ was the same in both sampling times. Unlike, TW-RDI had high capacity to close stomata with the increase in evaporative demand at midday that protected it from a drop in $\Psi_{\text {stem }}$ (Table 1). Consequently, the correlations between stomatal conductance and water potential was higher in early morning $\left(\Psi_{\text {stem }}=13.27 \mathrm{~g}_{\mathrm{s}}-2.13, \mathrm{R}=0.71, \mathrm{p}<0.005\right)$ than at midday $\left(\Psi_{\text {stem }}=17.24 \mathrm{~g}_{\mathrm{s}}-2.79, \mathrm{R}=0.68\right.$, $\mathrm{p}<0.01)$. Chlorophyll synthesis was negatively affected by irrigation with RW but not because of RDI (Table 1). Concretely, the $\mathrm{Chl} b$ pigment was reduced to a greater extent than the Chl a pigment (by $39 \%$ the $\mathrm{Chl} \mathrm{a}$, and by $46 \%$ the $\mathrm{Chl} \mathrm{b}$ ), giving rise to a significant increase in the $\mathrm{Chl} \mathrm{a/b}$ coefficient of the RW trees respect to the control (by 13\%) (Table 2). There were no significant correlations between ChlT and $\Psi_{\text {stem }}$ or $g_{s}$. From $t_{1}$ to $t_{2}$, the TW treatments (FI and RDI) significantly decreased the $\Psi_{\text {stem }}$ and the $g_{s}$. The RW trees also reduced the $\Psi_{\text {stem, as expected, although maintained the same stomatal }}$ regulation over time (similar values of $\mathrm{g}_{\mathrm{s}}$ in both samplings) and increased the $\mathrm{Chl} \mathrm{T}$ level at $\mathrm{t}_{2}$ respect to $t_{1}$. 
Table 1. Physiological parameters: stem water potential $\left(\Psi_{\text {stem }}, \mathrm{MPa}\right)$, stomatal conductance $\left(\mathrm{g}_{\mathrm{s}}\right.$, $\left.\mathrm{mol} \cdot \mathrm{m}^{-2} \cdot \mathrm{s}^{-1}\right)$ and total leaf chlorophyll content $\left(\mathrm{Chl} \mathrm{T}, \mathrm{mg} \cdot \mathrm{g}^{-1} \mathrm{FM}\right)$, at $\mathrm{t}_{1}(08.00 \mathrm{GMT})$ and at $\mathrm{t}_{2}(11.00$ GMT) on DOY 257 for each treatment: TW-FI (transfer water-full irrigation), TW-RDI (transfer water-regulated deficit irrigation), RW-FI (reclaimed water-full irrigation) and RW-RDI (reclaimed water-regulated deficit irrigation). Each value is the average \pm SD of eight individual trees. Different letters in the same row indicate significant differences among treatments according to Tukey's test $(p<0.05)$. Asterisk indicates significant differences between time samplings for the same treatment according to repeated measures ANOVA (* $\mathrm{p}<0.05)$.

\begin{tabular}{llllll}
\hline Parameter & Sampling time & TW-FI & TW-RDI & RW-FI & RW-RDI \\
\hline \multirow{2}{*}{$\Psi_{\text {stem }}$} & $\mathbf{t}_{1}$ & $-0.68 \pm 0.02 \mathrm{c}^{*}$ & $-1.06 \pm 0.02 \mathrm{~b}^{*}$ & $-1.01 \pm 0.08 \mathrm{~b}^{*}$ & $-1.85 \pm 0.11 \mathrm{a}^{*}$ \\
\cline { 2 - 6 } & $\mathbf{t}_{2}$ & $-1.20 \pm 0.07 \mathrm{c}$ & $-1.70 \pm 0.07 \mathrm{~b}$ & $-1.66 \pm 0.10 \mathrm{~b}$ & $-2.37 \pm 0.13 \mathrm{a}$ \\
\hline \multirow{2}{*}{$\mathbf{g}_{\mathbf{s}}$} & $\mathbf{t}_{1}$ & $0.11 \pm 0.03 \mathrm{c}^{*}$ & $0.07 \pm 0.02 \mathrm{~b}^{*}$ & $0.06 \pm 0.01 \mathrm{~b}$ & $0.05 \pm 0.01 \mathrm{a}$ \\
\hline \multirow{2}{*}{$\mathbf{C h l T}$} & $\mathbf{t}_{2}$ & $0.08 \pm 0.01 \mathrm{~b}$ & $0.04 \pm 0.01 \mathrm{a}$ & $0.07 \pm 0.01 \mathrm{~b}$ & $0.05 \pm 0.01 \mathrm{a}$ \\
\cline { 2 - 6 } & $\mathbf{t}_{1}$ & $1.97 \pm 0.13 \mathrm{~b}$ & $1.64 \pm 0.25 \mathrm{~b}$ & $0.97 \pm 0.13 \mathrm{a}^{*}$ & $1.11 \pm 0.13 \mathrm{a}^{*}$ \\
\hline
\end{tabular}

Table 2. Chlorophyll a (Chl a), chlorophyll b (Chl b) and coefficient $a / b(C o e f a / b)$ at $t_{1}(08.00$ GMT) and at $t_{2}$ (11.00 GMT) on DOY 257 for each treatment: TW-FI (transfer water-full irrigation), TW-RDI (transfer water-regulated deficit irrigation), RW-FI (reclaimed water-full irrigation) and RW-RDI (reclaimed water-regulated deficit irrigation). Each value is the average \pm SD of eight individual trees. Different letters in the same row indicate significant differences among treatments according to Tukey's test $(\mathrm{p}<0.05)$. Asterisk indicates significant differences between time samplings for the same treatment according to repeated measures ANOVA $\left({ }^{*} \mathrm{p}<0.05\right)$.

\begin{tabular}{llllll}
\hline Parameter & Sampling time & TW-FI & TW-RDI & RW-FI & RW-RDI \\
\hline \multirow{2}{*}{ Chl a } & $\mathbf{t}_{1}$ & $1.50 \pm 0.10 \mathrm{c}$ & $1.24 \pm 0.19 \mathrm{~b}$ & $0.76 \pm 0.11 \mathrm{a}$ & $0.86 \pm 0.10 \mathrm{a}$ \\
& $\mathbf{t}_{2}$ & $1.48 \pm 0.12 \mathrm{c}$ & $1.14 \pm 0.14 \mathrm{~b}$ & $0.89 \pm 0.29 \mathrm{a}$ & $1.11 \pm 0.10 \mathrm{ab}$ \\
\hline \multirow{2}{*}{$\mathrm{Chl} \mathrm{b}$} & $\mathbf{t}_{1}$ & $0.47 \pm 0.04 \mathrm{c}$ & $0.39 \pm 0.06 \mathrm{~b}$ & $0.21 \pm 0.03 \mathrm{a}$ & $0.24 \pm 0.03 \mathrm{a}$ \\
& $\mathbf{t}_{2}$ & $0.47 \pm 0.03 \mathrm{c}$ & $0.35 \pm 0.05 \mathrm{~b}$ & $0.25 \pm 0.08 \mathrm{a}$ & $0.31 \pm 0.04 \mathrm{ab}$ \\
\hline \multirow{2}{*}{ Coef $\mathbf{a} / \mathbf{b}$} & $\mathbf{t}_{1}$ & $3.16 \pm 0.07 \mathrm{a}$ & $3.17 \pm 0.08 \mathrm{a}$ & $3.61 \pm 0.10 \mathrm{~b}$ & $3.53 \pm 0.11 \mathrm{~b}$ \\
& $\mathbf{t}_{2}$ & $3.18 \pm 0.11 \mathrm{a}$ & $3.22 \pm 0.11 \mathrm{a}$ & $3.61 \pm 0.12 \mathrm{~b}$ & $3.57 \pm 0.11 \mathrm{~b}$ \\
\hline
\end{tabular}

A higher content of phytotoxic elements as $\mathrm{Na}^{+}$(by 76.9 and $46.2 \%$ for RW-FI and RW-RDI, respectively) and $\mathrm{Cl}^{-}$(by 33.3 and $12.1 \%$ for RW-FI and RW-RDI, respectively) was found in the RW treatments respect to the control, although there were no significant differences among treatments. A moderate osmotic adjustment $(\mathrm{OA})$ was presented in the RW treatments $(0.20$ and $0.23 \mathrm{MPa}$ for RW-FI and RWRDI, respectively) (Table 3).

Table 3. Leaf osmotic potential at full turgor $\left(\Psi_{100 s}\right)$ at midday, osmotic adjustment (OA) and leaf phytotoxic elements on DOY 257 for each treatment: TW-FI (transfer water-full irrigation), TWRDI (transfer water-regulated deficit irrigation), RW-FI (reclaimed water-full irrigation) and RWRDI (reclaimed water-regulated deficit irrigation). Each value is the average \pm SD of four individual 
trees. Different letters in the same row indicate significant differences among treatments according to Tukey's test $(\mathrm{p}<0.05)$.

\begin{tabular}{|c|c|c|c|c|}
\hline Treatment & $\begin{array}{l}\mathrm{Cl}^{-} \\
(\%)\end{array}$ & $\begin{array}{l}\mathrm{Na}^{+} \\
(\%)\end{array}$ & $\begin{array}{l}\Psi_{100 s} \\
(\mathrm{MPa})\end{array}$ & $\begin{array}{l}\text { OA } \\
\text { (MPa) }\end{array}$ \\
\hline TW-fI & $0.33 \pm 0.08 \mathrm{a}$ & $0.013 \pm 0.001 a$ & $-1.14 \pm 0.06 a$ & - \\
\hline TW-nI & $0.25 \pm 0.05 a$ & $0.016 \pm 0.002 a$ & $-1.08 \pm 0.09 a$ & +0.06 \\
\hline RW-fI & $0.44 \pm 0.05 \mathrm{a}$ & $0.023 \pm 0.005 a$ & $-1.34 \pm 0.11 b$ & -0.20 \\
\hline RW-nI & $0.37 \pm 0.11 \mathrm{a}$ & $0.019 \pm 0.001 a$ & $-1.37 \pm 0.13 b$ & -0.23 \\
\hline
\end{tabular}

Overall, the lowest stem water potential was displayed in the RDI treatments, mainly in the trees which combined both water and saline stresses, followed by the trees full irrigated with RW. This reduction of water potential led to a stomatal closure in all stressed treatments respect to the control, according to RomeroTrigueros et al. (2021b). Leaf chlorophyll content was affected by irrigation with saline RW in both sampling times, according to the results shown in [27] for citrus seedlings and in [7,3] for mandarin and grapefruit, but not by the water stress generated with the RDI. The differences in Chl T between the TW and RW treatments were smaller at midday than at predawn since the trees irrigated with RW increased their values from $t_{1}$ to $t_{2}$ because the increase in the Tc directly affected the accumulation of chlorophyll in leaves, as reported [28] for wheat leaves. Nevertheless, there is a lack of knowledge about the diurnal changes of chlorophyll in the recent literature. When the evaporative demand was higher, at midday, the non-saline treatments (TW trees) regulated stomata to slow the drop in water potential. On the contrary, the saline RW treatments presented a slight osmotic adjustment that maintained the stomatal opening at levels similar to those obtained at predawn. Thus, the light accumulation of salts as $\mathrm{Cl}^{-}$and $\mathrm{Na}^{+}$in the $\mathrm{RW}$ leaf did not cause a specific ion effect affecting the gas exchange, if not an osmotic effect, causing a higher water deficit. These plants performed an osmotic adjustment increasing osmotic potential at full turgor, as mechanisms to adapt to osmotic stress, which maintained the leaf turgor required to keep stomata open and sustain gas exchange $[14 ; 29,30]$. Nevertheless, RW-RDI continued with a $g_{s}$ significantly lower than control, as at predawn.

\subsection{Effects of water and saline stress on the thermal indices at canopy level. Relationships between physio-} logical parameters and thermal indices.

The Tc and the difference between Tc-Ta increased significantly at $t_{2}$ in the RW-FI and mainly in both RDI treatments, respect to the control. RW-RDI reached the highest levels at $t_{2}$. The treatments TW-RDI and RW-FI had similar values of Tc at $t_{2}$; however, when the values of Tc were normalized with air temperature (Ta), the higher significantly values of Tc-Ta were found in RW-FI. Thus, the normalization of Tc by Ta showed more significant differences among treatments than the value of Tc without normalizing. The Tc increased in all trees from $t_{1}$ to $t_{2}$, as expected, and the Tc-Ta values decreased. The CWSI was also significantly higher in the RW-FI and RDI treatments, mainly in RW-RDI at $t_{1}$. The CWSI was generally similar in both sampling times. Respect to the $\mathrm{I}_{\mathrm{G}}$, all treatments decreased it $v s$ control (TW-FI>TW-RDI $>$ RW-FI $>$ RW-RDI). The $I_{G}$ index decreased from $t_{1}$ to $t_{2}$, agreement with $\mathrm{g}_{\mathrm{s}}$ data (Table 4).

Table 4. Thermal indicators: canopy temperature $\left(\mathrm{Tc}^{\circ}{ }^{\circ} \mathrm{C}\right)$, difference between canopy and air temperature $\left(\mathrm{Tc}-\mathrm{Ta},{ }^{\circ} \mathrm{C}\right)$, crop water stress index (CWSI) and stomatal conductance index $\left(\mathrm{I}_{\mathrm{G}}\right)$ at $\mathrm{t}_{1}$ 


\section{Congreso Nacional de Riegos CARTAGENA 2021

(08.0 GMT) and at $t_{2}(11.00$ GMT) on DOY 257 for each treatment: TW-FI (transfer water-full irrigation), TW-RDI (transfer water-regulated deficit irrigation), RW-FI (reclaimed water-full irrigation) and RW-RDI (reclaimed water-regulated deficit irrigation). Tc was collected by thermography. Each value is the average \pm SD of eight individual trees. Different letters in the same row indicate significant differences among treatments according to Tuckey's test $(\mathrm{p}<0.05)$. Asterisk indicates significant differences between time samplings for the same treatment according to repeated measures ANOVA $\left({ }^{*} \mathrm{p}<0.05\right)$.

\begin{tabular}{|c|c|c|c|c|c|}
\hline & & & ermography & & \\
\hline Thermal indicator & $\begin{array}{l}\text { Sampling } \\
\text { time }\end{array}$ & TW-FI & TW-RDI & RW-FI & RW-RDI \\
\hline \multirow{2}{*}{ Tc } & $\mathbf{t}_{1}$ & $31.49 \pm 1.24 \mathrm{a}^{*}$ & $33.00 \pm 1.16 \mathrm{a}^{*}$ & $32.67 \pm 1.33 a^{*}$ & $33.01 \pm 1.01 \mathrm{a}^{*}$ \\
\hline & $t_{2}$ & $33.35 \pm 1.80 \mathrm{a}$ & $35.69 \pm 1.27 \mathrm{~b}$ & $36.35 \pm 1.50 \mathrm{~b}$ & $37.97 \pm 1.45 c$ \\
\hline \multirow{2}{*}{ Tc-Ta } & $t_{1}$ & $9.37 \pm 1.95 a^{*}$ & $10.88 \pm 1.31 a^{*}$ & $10.55 \pm 0.86 a^{*}$ & $10.89 \pm 1.15 a^{*}$ \\
\hline & $t_{2}$ & $0.34 \pm 1.36 \mathrm{a}$ & $2.67 \pm 1.27 \mathrm{~b}$ & $3.31 \pm 1.55 c$ & $5.28 \pm 0.90 \mathrm{~d}$ \\
\hline \multirow{2}{*}{ CWSI } & $\mathbf{t}_{1}$ & $0.51 \pm 0.01 \mathrm{a}$ & $0.61 \pm 0.01 b$ & $0.69 \pm 0.04 b$ & $0.73 \pm 0.03 c^{*}$ \\
\hline & $t_{2}$ & $0.55 \pm 0.04 a$ & $0.61 \pm 0.03 \mathrm{ab}$ & $0.67 \pm 0.02 b$ & $0.66 \pm 0.05 b$ \\
\hline \multirow{2}{*}{$I_{G}$} & $\mathbf{t}_{1}$ & $3.62 \pm 0.02 b^{*}$ & $2.77 \pm 0.02 \mathrm{ab}^{*}$ & $2.67 \pm 0.02 a^{*}$ & $2.28 \pm 0.03 a^{*}$ \\
\hline & $t_{2}$ & $2.43 \pm 0.03 \mathrm{~d}$ & $1.69 \pm 0.03 c$ & $1.61 \pm 0.02 b$ & $1.50 \pm 0.02 \mathrm{a}$ \\
\hline
\end{tabular}

It is important to emphasize also that the CWSI (Table 4) detected the TW-RDI treatment had level of stress similar to that of RW-RDI at $t_{2}$ since it is theoretically a function of the relative transpiration [31]. This was not what the water potential measurements at leaf level reflected (Table 1) because the sensitivity of CWSI was attenuated in grapefruit trees by feedback of stomatal closure [14,32].

Significant correlations between physiological and thermal indicators were found (Table 5). The Tc and Tc-Ta indicators were significantly correlated with $\Psi_{\text {stem, }} \mathrm{g}_{\mathrm{s}}$ and $\mathrm{Chl} \mathrm{T}$ in both sampling times, being the level of significance lower for the $\mathrm{g}_{\mathrm{s}}$ at midday $\left(\mathrm{t}_{2}\right)$ and for the Chl $\mathrm{T}$ at early morning $\left(\mathrm{t}_{1}\right)$. The CWSI significantly correlated with $\Psi_{\text {stem }}$ and Chl $\mathrm{T}$ at both sampling times, and with $\mathrm{g}_{s}$ only at $\mathrm{t}_{1}$. The slopes were negative in all cases. The IG showed better relationship than the CWSI with the $g_{s}$ at $t_{2}$. Besides, its slope was positive. This is, the greater the stomatal opening, the greater the IG. Alike, the IG was also significantly correlated with $\Psi_{\text {stem }}$ and $\mathrm{Chl} \mathrm{T}$ at both sampling times. In general, the results were excellent, except when Tc, Tc-Ta and CWSI were correlated with the $\mathrm{g}_{\mathrm{s}}$ at midday because the average Tc of TW-RDI (35.69 \pm 1.27$)$ (Table 4) was lower than expected based on the $g_{s}$ data. This problem was solved by using the IG index. Therefore, our results were according to the literature which showed that infrared thermal imaging can be used to assess the crop water status under field conditions $[17,33]$.

Table 5. Coefficients of correlation $(R)$ and slope sign for linear regressions found between the thermal indicators: canopy temperature $\left(\mathrm{Tc},{ }^{\circ} \mathrm{C}\right)$, difference between canopy and air temperature $\left(\mathrm{Tc}-\mathrm{Ta},{ }^{\circ} \mathrm{C}\right)$, crop water stress index (CWSI) and stomatal conductance index $\left(\mathrm{I}_{\mathrm{G}}\right)$, with stem water potential $\left(\Psi_{\text {stem, }} \mathrm{MPa}\right)$, stomatal conductance $\left(\mathrm{g}_{\mathrm{s}}, \mathrm{mmol} \cdot \mathrm{m}^{-2} \cdot \mathrm{s}^{-1}\right)$ and total leaf chlorophyll content $\left(\mathrm{Chl} \mathrm{T,} \mathrm{mg} \cdot \mathrm{g}^{-1} \mathrm{FM}\right)$, at $\mathrm{t}_{1}(08.00$ GMT) and at $t_{2}(11.00 \mathrm{GMT})$ of grapefruits trees, regardless of irrigation treatments, on DOY $257 .{ }^{*} \mathrm{p}<0.05$, ${ }^{* *} \mathrm{p}<0.01,{ }^{* * *} \mathrm{p}<0.005$. 


\section{Congreso Nacional de Riegos CARTAGENA 2021}

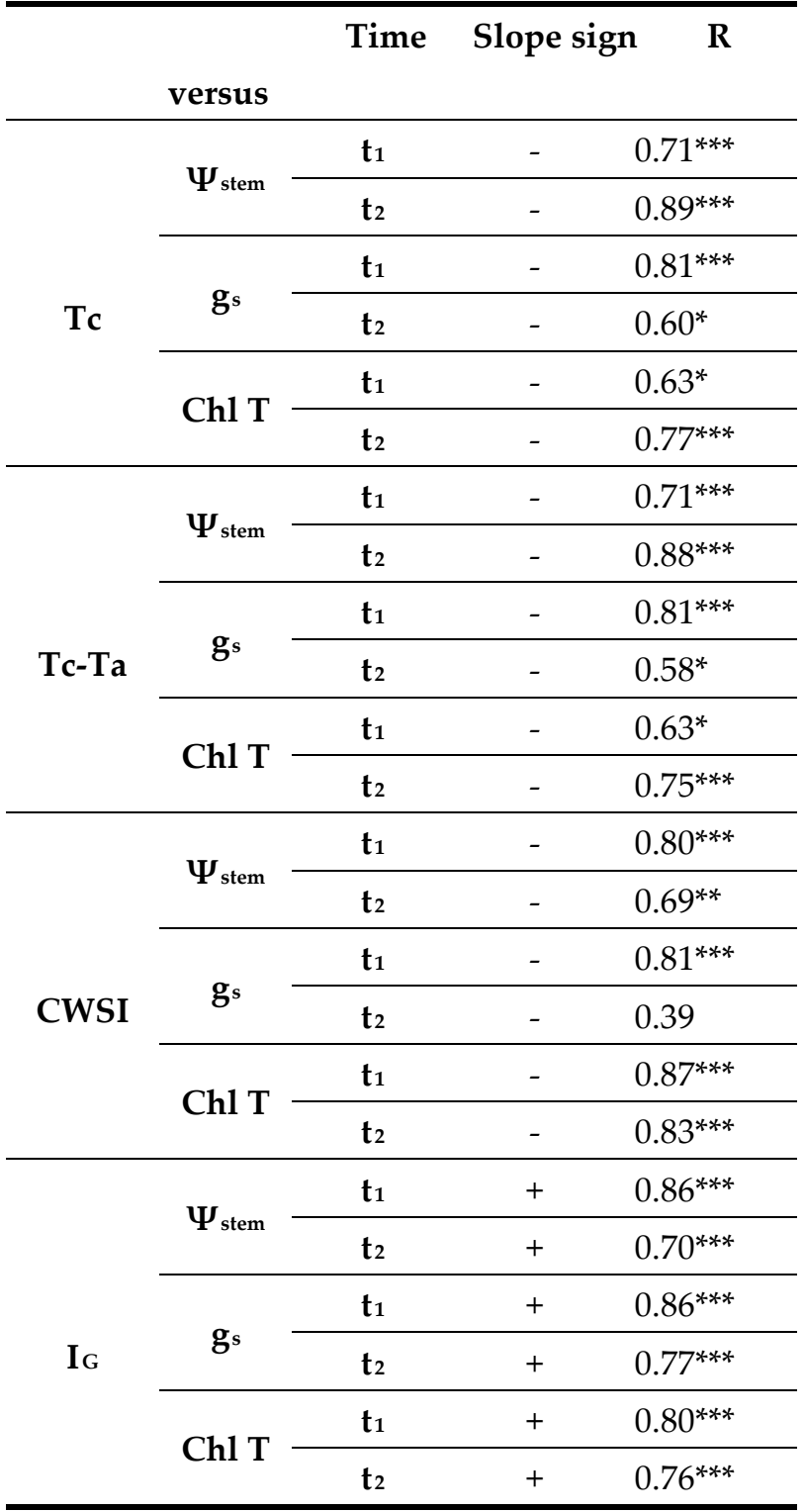

Here, data from thermography determined accurately the Tc of the grapefruits and did it agreement with the measured physiological parameters. In the particular case of the TW-RDI treatment, which important stomatal regulation from $t_{1}$ to $t_{2}(43 \%)$, the Tc values at solar noon were not as high as those of the RW-RDI treatment since this last one had a stomatal closure, of by $55 \%$ respect to the control, maintained over time $\left(t_{1}=t_{2}\right)$ that increased the Tc more than that of TW-RDI. Overall, the most suitable thermal indicators measured by thermography to estimate the diurnal changes in the physiological parameters were: Tc and Tc-Ta for stem water potential, IG for stomatal conductance and CWSI for $\mathrm{Chl} \mathrm{T}$. In addition, the IG was the index that better was related with the physiological parameters (higher significance in the coefficients of correlation) and specially with the $\mathrm{g}_{\mathrm{s}}$ at midday. As cited above, stomatal conductance was recently considered the best indicator of the water status of isohydric citrus [14]. Thus, we suggest here that the IG index measured by thermography was the more useful 
thermal indicator of grapefruits irrigated with saline RW and RDI. Finally, it was remarkable the advantage of thermography since leaf number analyzed by thermal camera was large. Besides, thermal images were taken in the same area where the physiological measurements were made, this is, from the sunlit side of the middle of the canopy, while other methods as thermometry were pointing from above of the trees, avoiding then those areas that could introduce significant noise in the results [25].

\section{Conclusions}

The usefulness of the thermal imaging (thermography) for monitoring the diurnal changes in the physiology of grapefruit trees irrigated with saline reclaimed water (RW) and/or regulated deficit irrigation (RDI) was assessed. Discrete physiological indicators as stem water potential, stomatal conductance and leaf total chlorophyll, and thermal indices (Tc, Tc-Ta, CWSI, and IG) were measured during a daily evolution. Results showed good relationships between all physiological and thermal data. Since stomatal conductance was defined the better indicator of the water status in isohydric citrus, it is suggested that the IG index is the more useful thermal indicator of the water status of grapefruits, making the thermography a promising tool for irrigation water management under these conditions of irrigation with saline RW and RDI. However, a manual segmentation for the extraction of the region of interest is required, which makes them unsuitable for continuous and autonomous measurement [34]. Future research should be directed to the design and validation of thermal image-based sensory platforms with automatic image processing.

\section{Referencias}

1. Zhao, H.R.; Qu, S.; Guo, S.; Liang, S.; Xu, M. Virtual water scarcity risk to global trade under climate change. J. Clean. Prod. 2019, 230, 1013-1026. https://doi.org/10.1016/j. jclepro.2019.05.114

2. Riemenschneider, C.; Al-Raggad, M.; Moeder, M.; Seiwert, B.; Salameh, E.; Reemtsma, T. Pharmaceuticals, their metabolites, and other polar pollutants in field-grown vegetables irrigated with treated municipal wastewater. J. Agric. Food Chem. 2016, 64 (29), 5784-5792. https://doi.org/10.1021/acs.jafc.6b01696

3. Romero-Trigueros, C.; Nortes, P.; Alarcón, J.J.; Hunink, J.E.; Parra, M.; Contreras, S.; Droogers, P.; Nicolás, E. Effects of saline reclaimed waters and deficit irrigation on Citrus physiology assessed by UAV remote sensing. Agric. Water Manag. 2017, 183, 60-69. https://doi.org/10.1016/j.agwat.2016.09.014.

4. Hristov, J.; Jesus Barreiro-Hurle, Guna Salputra, Maria Blanco, Peter Witzke, Reuse of treated water in European agriculture: Potential to address water scarcity under climate change, Agric. Water Manag. 2021, Volume 251, 106872, ISSN 0378-3774, https://doi.org/10.1016/j.agwat.2021.106872.

5. Nicolás, E.; Romero-Trigueros, C.; Nortes, P.A.; Pedrero, F.; Bayona, J.M.; Maestre-Valero, J.F.; Alarcón, J.J. Chapter 7: long-term physiological and agronomic responses of citrus irrigated with saline reclaimed water. Water Scarcity and Sustainable Agriculture in Semiarid Environment 2018 https://doi.org/10.1016/B978-0-12-813164- 0.00007-7 ISBN 978-012-813164-0.

6. Nicolás, E.; Alarcón, J.J.; Mounzer, O.; Pedrero, F.; Nortes, P.A.; Alcobendas, R.; Romero-Trigueros, C.; Bayona, J.M.; Maestre-Valero, J.F. Long-term physiological and agronomic responses of mandarin trees to irrigation with saline reclaimed water. Agric. Water Manag. 2016, 166, 1-8. https://doi.org/10.1016/j.agwat.2015.11.017.

7. Romero-Trigueros, C.; Nortes, P.A.; Pedrero, F.; Mounzer, M.; Alarcón, J.J.; Bayona, J.M.; Nicolás, E. Assessment of the viability of using saline reclaimed water in grapefruit in medium to long term. Span. J. Agric. Res. 2014a, 12 (4), $1137-$ 1148. https:// doi.org/10.1016/j.agwat.2016.09.014.

8. Romero-Trigueros, C.; Nortes, P.A., Alarcón, J.J., Nicolás, E. Determination of $15 \mathrm{~N}$ stable isotope natural abundances for assessing the use of saline reclaimed water in grapefruit. Environ. Eng. Manag. J. 2014b, 13, 2525-2530. https://doi.org/10.30638/eemj.2014.282.

9. Romero-Trigueros, C.; Parra, M.; Bayona, J.M.; Nortes, P.; Alarcón, J.J.; Nicolás, E. Effect of deficit irrigation and reclaimed water on yield and quality of grapefruits at harvest and postharvest. LWT Food Sci. Technol. 2017b, 85, 405-411. https://doi.org/10.1016/j. lwt.2017.05.001 


\section{Congreso Nacional de Riegos CARTAGENA 2021}

10. Romero-Trigueros, C.; Bayona, J.M.; Nortes, P.; Alarcón, J.J.; Nicolás, E. Determination of crop water stress index by thermometry in grapefruit trees irrigated with saline reclaimed water combined with deficit irrigation. Remote Sens. 2019a, 11 (7), 757. https://doi.org/10.3390/rs11070757.

11. Romero-Trigueros, C.; Vivaldi, G.A.; Nicolás, E.; Paduano, A.; Pedrero, F.; Camposeo, S. Ripening indices, olive yield and oil quality in response to irrigation with saline reclaimed water and deficit strategies. Front. Plant Sci. 2019b, 10, 1243. https://doi.org/ 10.3389/fpls.2019.01243.

12. Romero-Trigueros, C.; Alarcón, J.J.; Nortes, P.A.; Bayona, J.M.; Maestre-Valero, J.; Nicolás, E. Mid-long term effects of saline reclaimed water irrigation and regulated deficit irrigation on fruit quality of citrus. J. Sci. Food Agric. 2020, 100 (3), 1350-1357. doi: 10.1002/jsfa.10091.

13. Romero-Trigueros, C.; Díaz-López, M.; Vivaldi, G.A.; Camposeo, S.; Nicolás, E.; Bastida, F. Plant and soil microbial community responses to different water management strategies in an almond crop. Science of the Total Environment 2021a, 778 , art. no. 146148.

14. Romero-Trigueros, C.; Bayona, J.M.; Nortes, P.A, Alarcón, J.J.; Nicolás, E. Isohydric or anisohydric responses of two different Citrus under deficit irrigation and reclaimed water. Plant. 2021b. Accepted.

15. Giménez-Gallego, J.; González-Teruel, J.D.; Soto-Valles, F.; Jiménez-Buendía, M.; Navarro-Hellín, H.; Torres-Sánchez, R.; Intelligent thermal image-based sensor for affordable measurement of crop canopy temperature, Computers and Electronics in Agriculture, 2021, 188, 106319, ISSN 0168-1699, https://doi.org/10.1016/j.compag.2021.106319

16. Still, C.J.; Rastogi, B.; Gerald F.M.; Griffith, D.M.; Sibley, A.; et al. Imaging canopy temperature: shedding(thermal) light on ecosystem processes. New Phytologist 2021, 230, 1746-1753. doi: 10.1111/nph.17321

17. Ballester, C.; Jimenez-Bello, M.A.; Castel, J.R.; Intrigliolo, D.S. Usefulness of thermography for plant water stress detection in citrus and persimmon trees. Agric. Forest Meteorol. 2013, 168, 120-129

18. Yi, K.; Smith, J.; Jablonski, A.; Tatham, E.; Scanlon, T.; Lerdau, M.; Novick, K.; Yang, X. High heterogeneity in canopy temperature among co-occurring tree species in a temperate forest. J. Geophys. Res. Biogeosci. 2020, 125, e2020JG005892.

19. Blaya-Ros, P.J.; Blanco, V.; Domingo, R.; Soto-Valles, F.; Torres-Sanchez, R. Feasibility of low-cost thermal imaging for monitoring water stress in young and mature sweet cherry trees. Appl. Sci. 2020, 10 https://doi.org/10.3390/APP10165461.

20. Yang, W.; Wang, X.; Wheaton, A.; Cooley, N.; Moran, B. Automatic optical and IR image fusion for plant water stress analysis. In: 12th International Conference on Information Fusion. 2020, IEEE, Seattle, WA, USA, July 6-9, pp. $1053-1059$.

21. Osroosh, Y.; Khot, L.R.; Peters, R.T. Economical thermal-RGB imaging system for monitoring agricultural crops. Comput. Electron. Agric. 2018, 147, 34-43. https://doi.org/ 10.1016/j.compag.2018.02.018.

22. Blanco, V.; Blaya-Ros, P.J.; Castillo, C.; Soto-Vallés, F.; Torres-Sánchez, R.; Domingo, R. Potential of UAS-based remote sensing for estimating tree water status and yield in sweet cherry trees. Remote Sens. 2020, 12 https://doi.org/10.3390/RS12152359.

23. Zhang, L.; Zhang, Z.; Luo, Y.; Cao, J.; Tao, F. Combining optical, fluorescence, thermal satellite, and environmental data to predict county-level maize yield in China using machine learning approaches. Remote Sens. 2020, $12 \mathrm{https} / / \mathrm{doi} . \mathrm{org} /$ 10.3390/RS12010021.

24. Jones, H. G.; Stoll, M.; Santos, T.; de Sousa, C.; Chaves, M. M.; Grant, O. M. Use of infrared thermography for monitoring stomatal closure in the field: application to grapevine. J.Experiment. Bot. 2002, 53, 2249-2260.

25. Gomez-Bellot, M.P.; Nortes, P.A.; Sanchez-Blanco, M.J.; Ortuno, M.F. Sensitivity of thermal imaging and infrared thermometry to detect water status changes in Euonymus japonica plants irrigated with saline reclaimed water. Biosys. Engine. 2015, 133, 21-32. DOI10.1016/j.biosystemseng.2015.02.014

26. Idso, S.B. Non-water-stressed baselines: a key to measuring and interpreting plant water stress. Agric. Meteorol. 1982, 27, 59-70

27. Alam, A.; Ullah, H.; Attia, A.; Datta, A. Effects of Salinity Stress on Growth, Mineral Nutrient Accumulation and Biochemical Parameters of Seedlings of Three Citrus Rootstocks. Int. J. Fruit Sci. 2020, 20(4), 786-804. DOI 10.1080/15538362.2019.1674762

28. Friend, D.J. Control of chlorophyll accumulation in leaves of Marquis Wheat by temperature and light intensity.2. Chlorophyll contents relative to leaf area and thickness. Physiol. Plantarium 1961, 14, 28. DOI10.1111/j.13993054.1961.tb08134.x

29. Vivaldi, G.A.; Camposeo, S.; Lopriore, L.; Romero-Trigueros, C.; Pedrero, F. Using saline reclaimed water on almond grown in Mediterranean conditions: deficit irrigation strategies and salinity effects. Water Sci. Tech. Water Supply 2019, 19 (5), 1413-1421. https://doi.org/10.2166/ws.2019.008.

30. Vivaldi, G.A; Camposeo, S.; Romero-Trigueros, C.; Pedrero, F.; Caponio, G.; Lopriore, G., Álvarez, S. Physiological responses of almond trees under regulated deficit irrigation using saline and desalinated reclaimed water, Agric. Water Manag. 2021, 258, 107172, https://doi.org/10.1016/j.agwat.2021.107172. 


\section{Congreso Nacional de Riegos CARTAGENA 2021

31. Jackson, R.D.; Idso, S.B.; Reginato, R.J.; Pinter, P.J.; Water Resour. Res. 1981, 17(4), $1133-1138$. DOI10.1029/WR017i004p01133

32. Fereres, E.; Goldhamer, D.A. Deciduous fruit and nut trees. In: Irrigation of agricultural crops (Stewart BA \& Nielsen DR, Eds.). 1990, Am Soc Agron, Madison, WI, USA. Monograph 30, pp: 987-1017.

33. Garcia-Tejero, I.F.; Costa, J.M.; Egipto, R.; Duran-Zuazo, V.H.; Lima, R.S.N.; Lopes, C.M.; Chaves, M.M. Thermal data to monitor crop-water status in irrigated Mediterranean viticulture Agric. Water Manag. 2016, 176, 80-90 DOI10.1016/j.agwat.2016.05.008

García-Tejero, I.F.; Ortega-Arevalo, C.J.; Iglesias-Contreras, M.; Moreno, J.M.; Souza, L.; Tavira, S.C.; Duran-Zuazo, V.H. Assessing the crop-water status in almond (Prunus dulcis mill.) trees via thermal imaging camera connected to smartphone. Sensors (Switzerland) 2018, 18, 1-13. https://doi.org/10.3390/s18041050. 